\title{
HARDINESS DAN ADAPTABILITAS KARIR
}

\author{
Desia Wahyu Febrianingrum¹, Doddy Hendro Wibowo²
}

1,2Program Studi Psikologi Universitas Kristen Satya Wacana, email: 802017106@student.uksw.edu

\section{ABSTRACT: HARDINESS AND CAREER ADAPTABILITY}

Career adaptability is needed to assist students in facing and anticipating the challenges that may occur in entering the world of work. This study aims to determine the relationship between hardiness and career adaptability in vocational students. This study used a sample of 113 people who were students of class XII using the saturated sample technique. The measuring instruments used in this study are the Career Adapt-Abilities Scale (CAAS) and the Dispositional Resilience Scale (DSR-15). The data analysis technique used is the Pearson product moment correlation technique which shows the correlation coefficient value of $0.952(p<.001)$. So it can be interpreted that there is a significant positive relationship between hardiness and career adaptability of SMK "X" students in Ambarawa. The implication of this research is that having high hardiness will help students to achieve the desired career adaptability. This support student to prepare for a good career and play a better role in future jobs, including having the ability to cope with the unexpected situation in their career.

\section{Keywords: hardiness, career adaptability, vocational students}

Adaptabilitas karier sangat diperlukan untuk membantu siswa dalam menghadapi dan mengantisipasi tantangan yang mungkin terjadi dalam memasuki dunia kerja. Penelitian ini bertujuan untuk mengetahui hubungan antara hardiness dengan adaptabilitas karier pada siswa SMK. Penelitian ini menggunakan sampel sebanyak 113 orang yang merupakan siswa kelas XII menggunakan teknik sampel jenuh. Alat ukur yang digunakan dalam penelitian ini yaitu Career Adapt-Abilities Scale (CAAS) dan Dispositional Resilience Scale (DSR-15). Teknik analisis data yang dipakai adalah teknik korelasi pearson product moment yang menunjukan nilai koefisien korelasi sebesar 0,952 $(p<.001)$, maka dapat diartikan bahwa ada hubungan positif yang signifikan antara hardiness dengan adaptabilitas karier siswa SMK " $X$ " di Ambarawa. Implikasi dari hasil penelitian ini, yaitu dengan memiliki hardiness tinggi akan membantu siswa untuk mencapai adaptabilitas karier yang diinginkan. Hal ini mendukung siswa untuk mempersiapkan karir yang baik dan lebih berperan dalam pekerjaan nantinya termasuk memiliki kemampuan untuk mengatasi situasi yang tidak terduga dalam karier.

Kata kunci: adaptabilitas karier, hardiness,siswa SMK

\section{PENDAHULUAN}

Karier merupakan sebuah pilihan dalam setiap kehidupan manusia yang harus didasari dengan suatu perencanaan yang matang dan jelas, menurut Supriatna (2009) perencanaan karier merupakan peserta didik yang memiliki sikap positif terhadap kariernya dimasa depan dan dalam hal ini karier sangat penting bagi kehidupan manusia dan akan berkembang seterusnya. Lembaga pendidikan dengan bentuk pendidikannya berupa kejuruan yaitu SMK (Sekolah Menengah Kejuruan). Sekolah Menengah Kejuruan (SMK) yakni instansi pendidikan yang tujuannya secara khusus untuk mempersiapkan siswa supaya siap bekerja, baik itu mengisi lowongan pekerjaan yang ada maupun bekerja secara mandiri (Hasbullah, 2017). Namun, lulusan SMK yang diharapkan 


\section{HARDINESS DAN ADAPTABILITAS KARIR}

siap bekerja pada kenyataannya di Indonesia justru menjadi lulusan yang banyak menganggur.

Data yang dilansir oleh BPS (Badan Pusat Statistik) pada Agustus 2019 yang menunjukan jumlah pengangguran terbuka 7,05 juta orang, meningkat dari Agustus 2018 yang hanya 7 juta orang. Dalam paparannya, Kepala Badan Pusat Statistik Suhariyanto mengatakan, Tingkat Pengangguran Terbuka (TPT) didominasi oleh Iulusan Sekolah Menengah Kejuruan (SMK) sebesar 10,42\% pada Agustus 2019. "Tingkat pengangguran tertinggi adalah mereka yang berpendidikan SMK," kata Kepala BPS Suhariyanto di Jakarta, Selasa (5/11/2019).

Kemampuan menghadapi berbagai pilihan pada remaja tersebut sangat beragam, di antaranya yaitu berhubungan dengan proses dalam memilih karier yang sesuai akan nilai, kapasitas, serta minatnya (Sharf, 2016). Apakah mereka akan lanjut bekerja atau menuju jenjang Pendidikan yang lebih tinggi serta bagaimana pandangannya terkait suatu pekerjaan juga perlu untuk dipertimbangkan. Menurut Hirschi, (2009) bahwa menyiapkan masa depan vokasi termasuk tugas perkembangan remaja, oleh karenanya remaja harus didampingi dalam mempersiapkan kariernya.

Menurut hasil penelitian yang telah dilakukan oleh Ratih Rosulin dan Paramita (2016) hasil wawancara yang dilakukan dengan guru SMK Surabaya dan salah satu siswa SMK kelas XII juga menunjukan hal yang sama yang mana rata-rata siswa SMK belum memiliki pandanga dan rencana akan bekerja dimana setelah lulus nanti. Hasil ini mengindikasikan bahwa adaptabilitas karier siswa SMK cenderung rendah.

Hal ini sesuai dengan teori adaptabilitas karier yang didefinisikan sebagai kesiapan seseorang untuk mengatasi tugas yang sudah diperkirakan dalam pekerjaan, dan mampu memecahkan permasalahan yang kemungkinan muncul secara tidak terduga sebagai perubahan dalam situasi kerja (Savickas, 1997). Adaptabilitas karier mencangkup beberapa dimensi yang penting, yaitu kepedulian, pengendalian, keingintahuan, dan keyakinan (Savickas \& Profeli, 2012). Pada dunia yang penuh perubahan kerja dan lingkungan, konsep adaptabilitas karier bermanfaat untuk diteliti lebih lanjut pada remaja (Savickas, 2012). Pemilihan karier bukan suatu hal yang mudah, individu tidak lantas bisa memutuskan karier tanpa melakukan pertimbangan matang terhadap berbagai faktor yang dapat memengaruhi pemilihan karier.

Perubahan yang berlangsung secara cepat menimbulkan sulitnya memprediksi apa yang terjadi dikemudian hari. Fenomena ini juga mempengaruhi dunia kerja. Kondisi lingkungan yang dinamis menuntut seseorang untuk dapat bertahan dan menyesuaikan diri dengan kondisi lingkungan tersebut., sehingga seseorang harus memiliki kekuatan untuk dapat bertahan dalam kondisi yang penuh tantangan dan perubahan seperti yang terjadi saat ini.

Desia Wahyu Febrianingrum, Program Studi Psikologi Universitas Kristen Satya Wacana. Email: $\underline{802017106 @ s t u d e n t . u k s w . e d u}$

Doddy Hendro Wibowo, Program Studi Psikologi Universitas Kristen Satya Wacana. . Email: doddywibowo@uksw.edu 


\section{HARDINESS DAN ADAPTABILITAS KARIR}

Hardiness merupakan suatu karakteristik yang membuat individu menjadi lebih kuat, tahan, stabil, dan optimis dalam menghadapi situasi yang sulit dan mengurangi efek negatif yang dihadapi (Kobasa, 1979). Hardiness mempunyai kepercayaan terkait kegiatan dalam pengalaman hidup yang bisa dikontrol dan diramalkan (Hadjam \& Martaniah, 2004). Seseorang dengan hardiness yang cukup yaitu seseorang yang dapat bertahan di berbagai kondisi yang mendesak dan sulit. Hardiness merupakan sebuah cara pandang positif terhadap peristiwa yang dialami oleh individu meningkatkan standar hidup serta mengubah hambatan yang ada menjadi sumber pertumbuhan (Olivia, 2014).

Penelitian yang sudah ada menunjukan bahwa hardiness dapat meningkatkan kesiapan dan kepercayaan diri seseorang dalam memasuki dunia kerja (Greenleaf, 2011). Penelitian terdahulu menurut Schultz dan Schultz (2002), seseorang dengan tingginya tingkat hardiness akan cenderung mempunyai sikap yang menjadikannya mampu melawan situasi yang sulit. Seseorang dengan hardiness rendah cenderung melihat rendah kemampuan yang dimilikinya, cenderung diatur oleh nasib, dan tidak berdaya. Selain itu juga bisa memicu kurangnya harapan, mudah menyerah saat mengalami kondisi sulit, membatasi usaha, oleh karenanya akan memicu banyak kegagalan dalam hidup.

Hardiness dapat membantu siswa beradaptasi dengan keadaan yang menekan,

Desia Wahyu Febrianingrum, Program Studi Psikologi Universitas Kristen Satya Wacana. Email: 802017106@student.uksw.edu

Doddy Hendro Wibowo, Program Studi Psikologi Universitas Kristen Satya Wacana. . Email: doddy wibowo@uksw.edu sehingga siswa cenderung tidak cepat memiliki perasaan negatif atau mudah terbawa emosi, hardiness juga memacu siswa untuk terus maju, terus menjadi lebih baik, dan menjadi pribadi yang terus bertumbuh (Skomorovsky \& Sudom, 2011). Hardiness sangat diperlukan oleh siswa saat hendak masuk dalam dunia kerja atau bertahan di dalamnya. Adaptabilitas karier penting untuk individu tingkatkan guna mempercepat proses adaptasi terhadap lingkungan kerja baru, rekan, aturan, hingga mencapai kesuksesan karier (Savickas, 2012). Berdasarkan penelitian terdahulu yang dilakukan oleh Ratih Rosulin dan Paramita (2016) hasil analisis data menunjukan bahwa antara hardiness dengan adaptabilitas karier pada siswa terdapat hubungan yang signifikan.

Penjelasan-penjelasan diatas menunjukan bahwa adaptabilitas karier dan hardiness sangat penting terutama bagi siswa SMK kelas XII karena adaptabilitas karier dapat membantu siswa SMK kelas XII yang akan segera lulus untuk mempersiapkan diri memasuki dunia kerja sedangkan hardiness dapat membantu siswa SMK kelas XII untuk menghadapi kondisi lingkungan kerja yang penuh dengan tekanan dan kondisi yang berubah secara drastis. Dengan demikian penelitian ini bertujuan untuk mengetahui apakah ada hubungan antara hardiness dengan adaptabilitas karier pada siswa SMK kelas XII. 


\section{HARDINESS DAN ADAPTABILITAS KARIR}

\section{METODE PENELITIAN}

Pengambilan data menggunakan teknik survey dengan melibatkan siswa SMK. Teknik sampling yang digunakan yaitu sampling jenuh atau sensus yaitu teknik penentuan sampel bila semua anggota populasi digunakan sebagai sampel, dengan sejumlah 113 siswa SMK yang terdiri dari laki-laki dan perempuan. Peneliti melakukan waktu 2 minggu untuk pengambilan data melalui google form. Responden dalam penelitian ini $72 \%$ berjenis kelamin perempuan dan 28\% laki-laki serta berusia 16-21 tahun.

Peneliti menggunakan alat ukur Adaptabilitas Karier dengan menerjemahkan dari Career Adapt-Abilities Scole (CAAS) yang dikembangkan oleh Savickas (2012) terdiridari 24 item. Setiap item menggunakan empat kategori jawaban, yaitu SS (Sangat Sesuai), S (Sesuai), TS (Tidak Sesuai), STS (Sangat Tidak Sesuai). Contoh item pernyataan misalnya: "Saya tidak peduli dengan masa depan saya"; "Saya memikirkan apa yang akanmenjadi masa depansaya". Uji reliabilitas dan validitas menunjukkan nilai koefisien reliabilitas Alpha Cronbach pada alat ukur adaptabilitas karier sebesar .825 dan dapat dikatakan bahwa skala ini reliable.

Peneliti menggunakan alat ukur hardiness dengan Dispositional Resilience Scale (DRS-15) yang disusun oleh Bartone (2007). Alat ukur ini mengacu pada teori Kobasa (1979) yang terdiri dari tiga aspek hardiness, ketiga aspek tersebut adalah control, comitment, challenge. Dispositional Resilience Scaleterdiridari 15 item. Setiap item menggunakan empat kategori jawaban, yaitu SS (Sangat Sesuai), S (Sesuai), TS (Tidak Sesuai), STS (Sangat Tidak Sesuai). Contoh item pernyataan misalnya: "Dengan bekerja keras, saya dapat mencapai tujuan yang saya ingin capai" ; "Saya merasa hidup saya terkadang tidak memiliki makna". Ada pun cara memberikan jawaban dengan memberikan tanda centang $(\sqrt{ })$ pada salah satu pilihan jawaban. Uji reliabilitas dan validitas menunjukkan nilai koefisien reliabilitas Alpha Cronbach pada alat ukur hardiness sebesar .737 dan dapat dikatakan bahwa skala ini reliable.

Teknik analisis data dalam penelitian ini menggunakan: Uji normalitas dengan menggunakan metode Kolmogorov-Smirnov untuk melihat normalitas distribusi sebaran datanya. Uji linearitas digunakan untuk melihat hubungan antar variabel yang hendak untuk dianalisis mengikuti garis lurus atau tidak, yaitu apabila terjadi peningkatan atau penurunan kuantitas pada satu variabel maka secara linear akan diikuti oleh peningkatan atau penurunan kuantitas pada variabel yang lain (Singgih, 2010). Untuk uji hipotesis dalam penelitian ini menggunakan koefisien korelasi pearson product moment dengan bantuan SPSS versi 21 for windows.

Desia Wahyu Febrianingrum, Program Studi Psikologi Universitas Kristen Satya Wacana. Email: 802017106@student.uksw.edu

Doddy Hendro Wibowo, Program Studi Psikologi Universitas Kristen Satya Wacana. . Email: doddywibowo@uksw.edu 
HASIL

Tabel 1

Data Deskriptif Adaptabilitas Karier dan Hardiness

\begin{tabular}{|c|c|c|c|c|}
\hline Kategori & \multicolumn{2}{|c|}{ Adaptabilitas Karier } & \multicolumn{2}{|c|}{ Hardiness } \\
\hline & $\mathrm{F}$ & $\%$ & $\mathrm{~F}$ & $\%$ \\
\hline Rendah & 2 & $2 \%$ & 4 & $4 \%$ \\
\hline Sedang & 24 & $21 \%$ & 27 & $24 \%$ \\
\hline Tinggi & 87 & $77 \%$ & 82 & $72 \%$ \\
\hline Total & 113 & $100 \%$ & 113 & $100 \%$ \\
\hline
\end{tabular}

(77\%) dan hardiness yang juga tinggi (72\%).

Tabel 2

Hasil Uji Hipotesis

\begin{tabular}{ll}
\hline Variabel & Adaptabilitas Karir \\
\hline Hardiness & $.952^{* *}$ \\
\hline${ }^{* *} p<.01$ &
\end{tabular}

Berdasarkan pada tabel diatas, dapat disimpulkan terdapat hubungan positif signifikan antara hardiness dengan adaptabilitas karir $(r(113)=.952, p<.01)$. Hubungan yang ditemukan sangat kuat karena nilai korelasi sangat dekat dengan 1

\section{DISKUSI}

Hasil penelitian ini menunjukkan adanya hubungan positif signifikan yang sangat kuat antara hardiness dengan adaptabiltas karir. Artinya, semakin tinggi hardiness pada siswa maka semakin tinggi pula adaptabilitas karier. Hasil dari penelitian ini selaras akan penelitian sebelumnya dengan hasil yaitu ada hubungan antara hardiness dengan adaptabilitas karier (Coetsee \& Harry,2015).

Siswa yang memiliki tingkat hardiness yang tinggi akan lebih percaya diri dalam membuat keputusan mengenai karier dibandingkan dengan siswa yang memiliki skor hardiness lebih rendah. Siswa yang memiliki hardiness tinggi akan lebih siap dalam menghadapi transisi dari sekolah ke dunia kerja. Mereka akan lebih memikirkan mengenai kariernya, lebih mampu meregulasi diri untuk meraih karier yang diinginkan, lebih banyak mengeksplorasi dunia kerja, dan lebih percaya diri dalam membuat keputusan kariernya. Perubahan situasi yang mereka alami akan mendorong mereka untuk beradaptasi karena mereka melihat perubahan tersebut sebagai kesempatan untuk berkembang bukan sebagai hambatan. Adaptabilitas karier juga memiliki dampak positif terhadap karier seseorang.

Desia Wahyu Febrianingrum, Program Studi Psikologi Universitas Kristen Satya Wacana. Email: $\underline{802017106 @ s t u d e n t . u k s w . e d u}$

Doddy Hendro Wibowo, Program Studi Psikologi Universitas Kristen Satya Wacana. . Email: doddy wibowo@uksw.edu 


\section{HARDINESS DAN ADAPTABILITAS KARIR}

Adaptabilitas karier yang tinggi membuat seseorang lebih banyak memproyeksikan diri pada masa depan, merasakan lebih sedikit hambatan karier, lebih mampu mewujudkan tujuan karier kedalam perilaku (Negru-Subtirica, Pop, \& Crocetti, 2015). Adaptabilitas karier juga dapat memfalisitasi transisi dari sekolah ke dunia kerja (Negru-Subtirica, Pop, \& Crocetti, 2015). Sebaliknya adaptabilitas karier yang rendah dapat mengakibatkan seseorang berkeinginan untuk keluar atau mengundurkan diri dari organisasi dengan memperoleh pekerjaan yang kualitasnya rendah dan pengangguran. Sejalan dengan hasil penelitian tersebut penelitian Greenleaf (2011) menemukan bahwa hardiness berhubungan dengan kesiapan dan kepercayaan diri dalam menghadapi transisi menuju dunia kerja. Menurut Greenleaf (2011) individu yang memiliki hardiness tinggi adalah yang paling siap menghadapi transisi karier karena mereka melihat transisi yang akan mereka lalui sebagai kesempatan untuk berkembang bukan sebagai hambatan.

Implikasi dari hasil penelitian ini, yaitu dengan memiliki hardiness tinggi akan membantu siswa untuk mencapai adaptabilitas karier yang diinginkan. Untuk mempersiapkan karier yang diinginkan, siswa yang memiliki hardiness tinggi akan membantu dalam mempersiapkan karier yang baik dan jika seseorang sudah mempersiapkan karier dengan baik, maka siswa mampu untuk mempersiapkan karier dan berperan dalam suatu pekerjaan, pendidikan serta dapat mengatasi situasi yang tidak terduga dalam karier dan pekerjaan.

Pada proses penelitian ini, peneliti menyadari bahwa dalam suatu penelitian pasti terjadi banyak kendala dan hambatan diantaranya yaitu waktu dan tempat penelitian. Karena keterbatasan waktu dan tempat penelitian, peneliti melibatkan guru dalam penyebaran kuesioner dikarenakan peneliti tidak dapat bertemu langsung dengan siswa dan penelitian ini tidak dapat digeneralisasikan secara lebih luas karena hanya menggunakan sampel yang spesifik. Peneliti menyarankan kepada penelitian selanjutnya dapat melakukan penelitian menggunakan variabel lain seperti mengenai hubungan antara dukungan orang tua dengan adaptabilitas karier seperi penelitian menurut Zahra (2018) yang menunjukan terdapat hubungan antara dukungan orang tua dengan adaptabilitas karier, yang artinya semakin tinggi dukungan orang tua maka semakin tinggi adaptabilitas karier pada siswa.

\section{SIMPULAN DAN SARAN}

Berdasarkan hasil penelitian ini didapat adanya hubungan positif signifikan antara hardiness dengan adaptabilitas karier pada siswa SMK "X" di Ambarawa. Artinya semakin tinggi hardiness semakin tinggi pula adaptabilitas karier, maka sebaliknya jika semakin rendah tingkat hardiness maka semakin rendah pula adaptabilitas karier.

Desia Wahyu Febrianingrum, Program Studi Psikologi Universitas Kristen Satya Wacana. Email: 802017106@student.uksw.edu

Doddy Hendro Wibowo, Program Studi Psikologi Universitas Kristen Satya Wacana. . Email: doddy wibowo@uksw.edu 


\section{HARDINESS DAN ADAPTABILITAS KARIR}

Saran bagi peneliti selanjutnya yang ingin melakukan penelitian mengenai adaptabilitas karier diharapkan agar memperhatikan sampel yang akan digunakan. Berdasarkan hasil penelitian yang dilakukan, keterbatasan pada penelitian ini hendaknya diperhatikan dan untuk peneliti selanjutnya juga lebih melengkapi data sesuai dengan keterbatasan penelitian ini, sehingga dapat tercapai hasil yang sempurna pada penelitian selanjutnya.

\section{DAFTAR PUSTAKA}

Bartone, P. T. (2007). Test-retest reliability of the dispositional resilience scale-15, a brief hardiness scale. Psychological Reports, 101, 943-944, doi: 10.2466/PR0.101.7.943-944

Coetsee, M., \& Harry, N. (2015). Gender and hardiness as predictors of career adaptability: an exploratory study among black call centre agents. South African Journal of Psychology, 45 (1), 81-92

Greenleaf, A. T. (2011). Human agency, hardiness, and proactive personality: potential resources for emerging adults in the college-to-career transition.

Hadjam, R., \& Martaniah, S. M. (2004). Peran kepribadian tahan banting pada gangguan somatisasi. Anima, Indonesian Psychological Journal, 19(2), 122-135.

Hasbullah, H. (2017). Dasar-Dasar Ilmu Pendidikan Edisi revisi. Rajawali Pers.

Hirschi, A. (2009). Career adaptability development in adolescence: Multiple predictors and effect on sense of power and life satisfaction. Journal of vocational behavior, 74(2), 145-155.
Huang, J. T. (2015). Hardiness, perceived employability, and career decision selfefficacy among Taiwanese college students. Journal of Career Development, 42(4), 311-324.

Kobasa, S. C. (1979). Stressful life events, personality, and health: an inquiry into hardiness. Journal of personality and social psychology, 37(1), 1.

Negru-Subtirica, O., Pop, E. I., \& Crocetti, E. (2015). Developmental trajectories and reciprocal associations between career adaptability and vocational identity: A three-wave longitudinal study with adolescents. Journal of vocational behavior, 88, 131-142.

Olivia, D. O. (2014). Kepribadian tahan banting dengan prestasi kerja pada karyawan bank. Jurnal IImiah Psikologi Terapan, 02(01),115.

Rosulin, R., \& Paramita, P. P. (2016). Hubungan antara hardiness dengan adaptabilitas karir pada siswa SMK kelas XII. Jurnal Psikologi Pendidikan dan Perkembangan, 5(1), 38-48.

Singgih, S. (2010). Statistik Parametrik Konsep dan Aplikasi dengan SPSS. Jakarta: PT. Elex Media Komputindo.

Savickas, M. L. (1997). Career adaptability: An integrative construct for life-span, lifespace theory. The career development quarterly, 45(3), 247-259.

Savickas, M. L., \& Porfeli, E. J. (2012). Career Adapt-Abilities Scale: Construction, reliability, and measurement equivalence across 13 countries. Journal of vocational behavior, 80(3), 661-673.

Savickas, M. L. (2012). Life design: A paradigm for career intervention in the 21st century. Journal of Counseling \& Development, 90(1), 13-19.

Desia Wahyu Febrianingrum, Program Studi Psikologi Universitas Kristen Satya Wacana. Email: 802017106@student.uksw.edu

Doddy Hendro Wibowo, Program Studi Psikologi Universitas Kristen Satya Wacana. . Email: doddy wibowo@uksw.edu 
Schultz, D., \& Schultz, S. E. (2002). Psycology and Work Today. Eight Edition. New Jersey: Prentice Hall.

Sharf, R. S. (2016). Applying career development theory to counseling. Cengage Learning.

Skomorovsky, A., \& Sudom, K. A. (2011). Psychological well-being of Canadian forces officer candidates: The unique roles of hardiness and personality. Military medicine, 176(4), 389-396

Supriatna, D. (2009). Pengenalan Media Pembelajaran, Pusat Pengembangan Dan Pemberdayaan Pendidik Dan Tenaga Kependidikan Taman Kanak Kanak Dan Pendidikan Luar Biasa. Sumber: http://izaskia. files. wordpress.

com/2010/03/pengenalanmediapembelajaran. pdf.

Zahra, A. (2018). Hubungan antara dukungan orangtua dengan adaptabilitas karir pada siswa (Doctoral dissertation, UIN Sunan Ampel Surabaya).

Desia Wahyu Febrianingrum, Program Studi Psikologi Universitas Kristen Satya Wacana. Email: 802017106@student.uksw.edu

Doddy Hendro Wibowo, Program Studi Psikologi Universitas Kristen Satya Wacana. . Email: doddy wibowo@uksw.edu 